\title{
A biostratigraphically well-constrained K-bentonite U-Pb zircon age of the lowermost Darriwilian Stage (Middle Ordovician) from the Argentine Precordillera
}

\begin{abstract}
New concordant zircon U-Pb ages from lower Middle Ordovician $K$-bentonites in the Argentine Precordillera yield an emplacement age of $464 \pm 2 \mathrm{Ma}$. These K-bentonites occur in the U. austrodentatus Zone, the lowermost graptolite zone of the Darriwilian Stage, which was recently ratified as a global stage by the ICS and IUGS. Because the estimated length of the U. austrodentatus Zone is no more than $\mathrm{I}-2 \mathrm{Ma}$, the new isotopic age, which is one of the biostratigraphically best constrained from the Ordovician, can be considered representative of the base of the Darriwilian Stage.
\end{abstract}

\section{Introduction}

As is well known, Ordovician fossil faunas exhibit some of the most striking biogeographical and ecological differentiation known anywhere in the geologic record. In addition, the lithological development of Ordovician successions shows profound differences in different regions. Not only has this made global correlations difficult but it has also led to the establishment of local stage and series schemes, the most widely used regionally being the British one. However, it has become quite clear that many, if not most, of the British Ordovician stages are difficult, if not impossible, to recognize with any precision on a global scale. In an effort to establish a globally useful stage and series classification of the Ordovician System, the International Subcommission on Ordovician Stratigraphy has embarked on a program focusing on identifying significant biostratigraphic levels that are suitable to serve as global stage and series boundaries, and to select appropriate stratotypes for these levels. In a formal vote in 1996, the Subcommission approved the Darriwilian Stage as a global stage in the Middle Ordovician Series, with its base defined as the base of the $U$. austrodentatus Zone in the stratotype section at Huangnitang, near Changshan, Zhejiang Province, southeastern China (Chen and Bergström, 1995a). This stage, and the stratotype section, have recently been ratified by the International Commission on Stratigraphy and the IUGS.

Unfortunately, the stratotype interval in the Huangnitang section, and coeval strata in other sections in the Changshan region, contain no rocks suitable for isotopic dating of the base of the Darriwilian Stage, and we are not aware of any record of the isotopic age of this important stratigraphic level from any locality outside China. The purpose of the present short paper is to report a $\mathrm{U}-\mathrm{Pb}$ zircon age from $\mathrm{K}$-bentonite beds at this level in a biostratigraphically exceptionally well-constrained section in the Precordillera of western Argentina. Evidence of explosive volcanism in the Precordillera during the Early and early Middle Ordovician was discovered in 1994 in the form of sequences of 30 or more K-bentonite beds (Figure 1) in the upper San Juan Limestone and lower Los Azules (or Gualcamayo) Formation of the eastern and central thrust belts (Kolata et al., 1994: Huff et al., 1995; Bergström et al., 1996). Geochemical analyses showed that the beds represent the altered rem- nants of vitric fallout ash from large-scale explosive volcanism associated with collision zone tectonism, and that the parental magmas were felsic in composition (Bergström et al., 1996). Preliminary $\mathrm{U}-\mathrm{Pb}$ zircon ages were reported by Huff et al. (1995) as $461 \pm 10 \mathrm{Ma}$ for the magmatic origin of the beds and an inheritance age of about $1900 \mathrm{Ma}$ was also revealed. We report here additional and better constrained zircon age measurements on a sample from the lower member of the Los Azules Formation at Cerro Viejo (30'11 '05' $\mathrm{S}$, $\left.68^{\circ} 35^{\prime} 05^{\circ} \mathrm{W}\right)$, near Jáchal in San Juan Province.

\section{CERRO VIEJO, SAN JUAN PROVINCE}

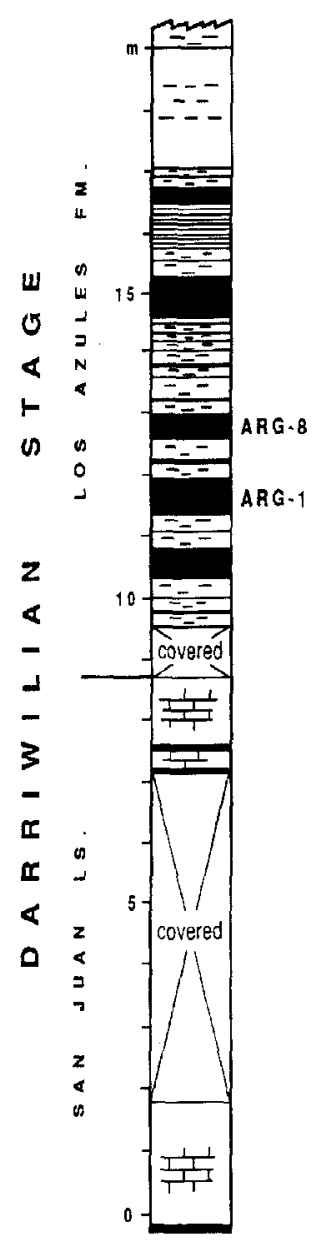

Undulograptus austrodentatus Graptolite Zone

Histiodella sinuosa Conodont Zone

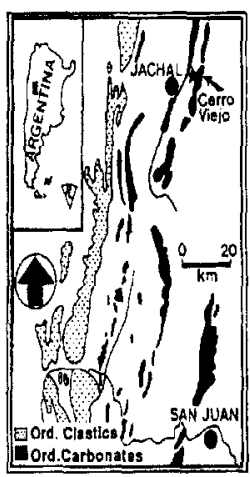

Figure 1 Location map and stratigraphic section of Middle Ordovician K-bentonites (black bands) exposed at Cerro Viejo, San Juan Province, Argentina. 
Figure 2 Classification of the K-bentonite section at Cerro Viejo in terms of stages and standard graptolite and conodont zones. Based mostly on faunal data reported by Ortega et al. (1996). The lower Darriwilian U. austrodentatus Zone (D1) is considered late Arenig in age (Cooper and Lindholm, 1992; Chen et al., 1995a).

\section{Biostratigraphy}

Excellent exposures of the upper part of the San Juan Limestone and virtually the entire thickness of the overlying Los Azules Formation occur in natural outcrops at Cerro Viejo. This succession ranges from the $U$. austrodentatus Zone to well up into the $N$. gracilis Zone, hence from the base to the top of the Darriwilian. The sequence is richly fossiliferous, having diverse graptolite, conodont, palynomorph, and shelly faunas (Ortega et al., 1996). Both graptolites and conodonts provide close biostratigraphic control of the dated $\mathrm{K}$ bentonite samples, which are from the lower member of the Los Azules Formation in an interval 2.5-4 m above the top of the San Juan Limestone (Figure 1). Both the preliminary and refined zircon ages come from adjacent K-bentonite beds at Cerro Viejo. The data reported by Huff et al. (1995) came from the basal portion of bed ARG-8, a $40 \mathrm{~cm}$ thick K-bentonite, and the new data come from zircons in the basal portion of ARG-1, a $55 \mathrm{~cm}$ thick K-bentonite located $1 \mathrm{~m}$ below ARG-8.

In terms of the locally used graptolite biostratigraphy, the samples ARG- 1 and ARG-8 come from strata having the fauna of the $P$. tentaculatus Zone (Ortega et al., 1996). This was confirmed by a large collection of graptolites from immediately below the level of ARG-1 (Bergström and Wang, 1995). However, the new graptolite data presented by Ortega et al. (1996) make it possible to classify the $\mathrm{K}$-bentonite interval in the more detailed lower Darriwilian graptolite zone scheme recently proposed by Chen et al. (1995a, 1995b). Using this classification, the samples ARG- 1 and ARG- 8 belong to the $U$. sinicus Subzone of the $U$. austrodentatus Zone and hence occupy a level in the lowermost graptolite zone in the Darriwilian. The level of the base of the $U$. austrodentatus Zone has not yet been recognized at Cerro Viejo but considering its known limited temporal range it is unlikely that it is very far below the top of the San Juan Limestone. Hence, based on index graptolites, our studied samples come from an interval that is just above the base of the Darriwilian Stage. Conodont evidence supports this dating. That is, Ortega et al. (1996) record key species of the Laurentian Histiodella sinuosa Zone from the very uppermost San Juan Limestone which is in agreement with the graptolite/conodont zone relations in North America (Bergström and Wang, 1995). Hünicken and Ortega (1987) illustrated fragmentary platform elements identified as Eoplacognathus suecicus and Polonodus tablepointensis from the topmost San Juan Limestone at Cerro Viejo and interpreted this level as representing the Baltoscandic Eoplacognathus suecicus Zone. But more recently, Ortega et al. (1996) classified this level as referable to the upper subzone of the Baltoscandic Amorphognathus variabilis Zone, a minor biostratigraphic adjustment downward that agrees better with the graptolite evidence. There is no published record of biostratigraphically diagnostic conodonts in the siliceous beds that surround the thick K-bentonites beds in the lowermost Los Azules Formation. For a summary of the biostratigraphy of the K-bentonite interval at Cerro Viejo, see Figure 2.

\section{Samples and methods}

Approximately $500 \mathrm{gm}$ of $\mathrm{K}$-bentonite sample were placed in a drying oven at $60^{\circ} \mathrm{C}$ overnight, then placed in a $1000 \mathrm{ml}$ beaker with just enough kerosene to submerge the sample. After 1 hr the kerosene. used to reduce the surface tension of water in fine-grained clay materials, was poured off and the beaker filled with deionized water. The samples began to disaggregate almost immediately, and following 1 minute agitation with a mechanical stirring device each sample was wet-sieved at $75 \mu \mathrm{m}$ using disposable polyester sieves. Zircons were concentrated by means of bromoform, magnetic, and methylene iodide separation. Final sample selection was by hand picking under a microscope. Exterior surfaces of selected uncracked zircon grains were removed by air abrasion. Weights of fractions were estimated by eye, a process that has been found to be usually accurate to about $\pm 30 \%$. This affects only $\mathrm{U}$ and $\mathrm{Pb}$ concentrations, not age information, which depends only on isotopic ratio measurements.

Zircon was dissolved using HF in Teflon bombs at $200^{\circ} \mathrm{C}$, after being washed in $\mathrm{HNO}_{3}$. A ${ }^{205} \mathrm{~Pb} /{ }^{235} \mathrm{U}$ spike was added to the dissolution capsules during sample loading. Purification of $\mathrm{Pb}$ and $\mathrm{U}$ was carried out in $\mathrm{HCl}$ using $0.05 \mathrm{ml}$ anion exchange columns.

$\mathrm{Pb}$ and $\mathrm{U}$ were loaded together on Re filaments using silica gel and analyzed with a VG354 mass spectrometer in single collector mode. Most of the measurements were made using a Daly collector. The mass discrimination correction for this detector has been monitored for several years and found to be constant at $0.40 \% / \mathrm{AMU}$.

\section{Results}

Results of isotopic measurements are given in Table 1 and plotted on Figure 3. Age errors based on regression, using the program of 
Davis (1982), are quoted at the $95 \%$ confidence level. Error ellipses in the figure are given at the 2 sigma level.

Table 1 gives isotopic data for samples ARG-1 and ARG-8. Sample ARG-8 comprised only a few dozen zircon grains, most of which are highly cracked. Only two fractions of uncracked zircons could be picked from this sample. The yield from ARG-1 was much better. The zircons are generally euhedral, moderately to highly elongated multi-faceted prisms, with small melt inclusions. There is no obvious evidence of cores in the zircon populations. Because of the small size, low uranium content, and Phanerozoic age of the zircons, it was necessary to analyze fractions containing several grains. These were picked to have uniform characteristics (morphology, and presence or absence of inclusions).

A concordia plot of analyses from both samples is shown in Figure 3. As reported by Huff et al. (1995), both ARG-8 grains had some inheritance and thus only discordant analyses resulted, with a projected lower concordia intercept of $461+7 /-10 \mathrm{Ma}$ and an imprecise upper concordia intercept age of about $1900 \mathrm{Ma}$. Three of the new analyses from ARG-1 are almost concordant, while one contains inheritance. These data give a much better defined lower intercept age of $464 \pm 2 \mathrm{Ma}$ and indicate a possible source of inheritance that is $1237 \pm 14$ Ma old. Because this inheritance age is defined by only one analysis of a multi-grain fraction, it is possible that it represents a meaningless average if the fraction contains inherited zircon from different sources. However, we consider that this is unlikely. Because the discordant fraction contained only four grains, while the other three fractions, with a total of 14 grains, do not show signifi- cant inheritance, inheritance is probably uncommon in this zircon population, so it is unlikely that there would be two inherited grains in the same fraction. In addition, the upper intercept age of $1897 \mathrm{Ma}$ from ARG-8 is likely to represent a single source of inheritance since it is determined from two discordant data points, which point toward an apparently reliable lower intercept age.

\section{Discussion}

Although quite a few isotopic ages have been recorded from the Ordovician (for a recent summary, see Tucker and McKerrow, 1995), few of these are from successions with precise fossil control. This applies also to those from Darriwilian strata. Zircons in rhyolite from the Buchans Group of Newfoundland, which contains limestone clasts of the Histiodella holodentata Zone (Nowlan and Thurlow, 1987), yielded an age of $465+3 /-2 \mathrm{Ma}$ (Stewart, 1987), hence in good agreement with the dates from Cerro Viejo that represent the next older conodont zone. Zircons from a rhyolite in the Cutwell Group of north-central Newfoundland produced an age of $469+5 /-3$ Ma (Dunning and Krogh, 1991). This group has yielded a few conodonts of apparent early Darriwilian age (Stouge, 1980) but the stratigraphical relations between the dated rhyolite and the conodont-bearing rocks are not known to us. A tuff above strata having graptolites of the Didymograptus artus Zone on the north-west flank of Arenig Fawr, Wales gives a U-Pb age of $465.7 \pm 2.1 \mathrm{Ma}$ (Tucker et al., 1990). Based on correlations presented by Chen et al.
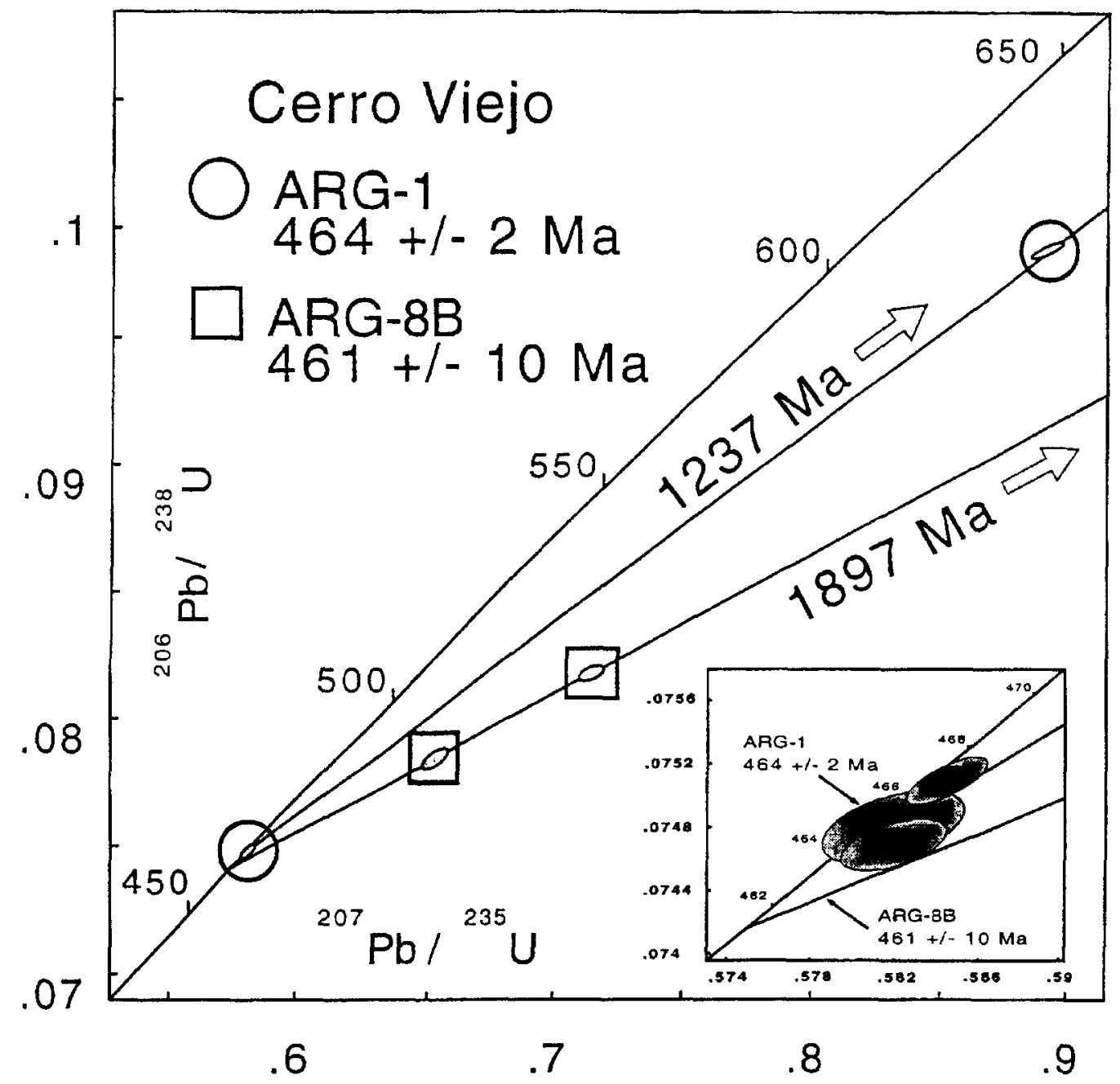

.9

Figure 3. U-Pb concordia plot showing 2 sigma error ellipses and upper and lower intercept ages for all data points. Analyses from ARG-1 are indicated by circles while those from $A R G-8 B$ are indicated by squares. The inset shows near-concordant 2 sigma error ellipses from sample ARG-1. Best-fit inheritance mixing lines and lower concordia intercept ages are also shown. (1995a), this tuff should be slightly younger than the dated $\mathrm{K}$-bentonites from Cerro Viejo, provided the biostratigraphic dating is correct. Finally, a rhyolitic tuff below shales of the Didymograptus murchisoni Zone, and above shales of the Didymograptus artus Zone, at Abereiddi Bay, southwestern Wales (Tucker et al., 1990) has given a $\mathrm{U}-\mathrm{Pb}$ zircon age of $464.6 \pm 1.8 \mathrm{Ma}$. There is no fossil evidence that can be used to refer this tuff to a particular graptolite zone although its isotopic age would suggest that it is likely to be coeval with a portion of the latter zone. As a whole, these isotope ages of rocks of the lower Darriwilian agree reasonably well with those from Cerro Viejo.

Finally, it is appropriate to note that Cooper (1992) estimated the length of the lower Darriwilian (the U. austrodentatus Zone (DI) and the ' $G$.' intersitus (D2) zones) to be of the order $3.7 \mathrm{Ma}$. Provided these zones are of about equal length, this suggests that the entire $U$. austrodentatus Zone would have a duration of only 1-2 Ma. The very base of the Darriwilian clearly is slightly older than the $\mathrm{U}-\mathrm{Pb}$ zircon age from Cerro Viejo but we estimate that the age difference is less than $1 \mathrm{Ma}$ and hence within the margin of error of our age date. Thus, the 
TableI. U-Pb systematic data for Cerro Viejo zircons

\begin{tabular}{|c|c|c|c|c|c|c|c|c|c|c|c|c|c|c|}
\hline Fraction Analyzed & $\begin{array}{c}\text { Weight } \\
\text { (mg) }\end{array}$ & $\begin{array}{c}\mathrm{U} \\
(\mathrm{ppm})\end{array}$ & $\mathrm{Th} / \mathrm{U}$ & $\begin{array}{c}\text { PbCOM } \\
\text { (pg) }\end{array}$ & $\begin{array}{l}206 \mathrm{~Pb} / \\
204 \mathrm{~Pb}\end{array}$ & $\begin{array}{c}206 \mathrm{~Pb} / \\
238 \mathrm{U}\end{array}$ & $\begin{array}{l}207 \mathrm{~Pb} / \\
235 \mathrm{U}\end{array}$ & $\begin{array}{l}206 / 238 \\
\text { Age(Ma) }\end{array}$ & $\begin{array}{c}1 \\
\text { sig }\end{array}$ & $\begin{array}{l}207 / 235 \\
\text { Age(Ma) }\end{array}$ & $\begin{array}{c}1 \\
\text { sig }\end{array}$ & $\begin{array}{l}207 / 206 \\
\text { Age(Ma) }\end{array}$ & $\begin{array}{c}1 \\
\text { sig }\end{array}$ & $\begin{array}{l}\text { Disc. } \\
(\%)\end{array}$ \\
\hline \multicolumn{15}{|l|}{ ARG-1 BENTONITE } \\
\hline $14 \mathrm{Zr}$ Ab equant & 0.008 & 184 & 0.68 & 2.5 & 2847 & 0.074812 & 0.58196 & 465.08 & 0.65 & 465.72 & 1.1 & 468.9 & 5.5 & 0.8 \\
\hline $24 \mathrm{Zr}$ Ab elongate & 0.008 & 153 & 1.25 & 2.0 & 3896 & 0.098435 & 0.89272 & 605.23 & 0.64 & 647.83 & 0.9 & 799.2 & 2.9 & 25.43 \\
\hline $34 \mathrm{Zr} \mathrm{Ab}$ equant, with incl & 0.008 & 271 & 0.64 & 3.0 & 3432 & 0.074679 & 0.58203 & 464.28 & 0.44 & 465.77 & 0.8 & 473.1 & 4.2 & 1.9 \\
\hline $46 \mathrm{Zr}$ Ab equant, few incl & 0.008 & 194 & 0.90 & 1.2 & 6426 & 0.075098 & 0.58466 & 466.80 & 0.44 & 467.45 & 0.6 & 470.7 & 2 & 0.9 \\
\hline \multicolumn{15}{|l|}{ ARG-8B BENTONITE } \\
\hline $56 \mathrm{Zr} \mathrm{Ab}$, abundant incl & 0.010 & 278 & 0.76 & 5.5 & 2682 & 0.081765 & 0.71479 & 506.65 & 0.63 & 547.59 & 1.0 & 721.8 & 4.1 & 31.0 \\
\hline $612 \mathrm{Zr} \mathrm{Ab}$, few incl & 0.010 & 326 & 0.71 & 5.5 & 3002 & 0.078470 & 0.65376 & 486.99 & 1.016 & 510.79 & 1.2 & 618.8 & 5.25 & 22.1 \\
\hline
\end{tabular}

\section{FOOTNOTES:}

$4 \mathrm{Zr}$ - 4 zircon grains; Ab-abraded; incl - inclusions

Errors are given at 1 sigma.

$\mathrm{PbCOM}$ - Common $\mathrm{Pb}$, including blank; calculated using blank isotopic composition.

$\mathrm{Th} / \mathrm{U}$ calculated from radiogenic $208 \mathrm{~Pb} / 206 \mathrm{~Pb}$ ratio and $206 \mathrm{~Pb} / 238 \mathrm{U}$ age Data corrected for 230th disequilibrium assuming magmatic $\mathrm{Th} / \mathrm{U}=4.2$ Disc, -per cent discordance for the given $207 \mathrm{~Pb} / 206 \mathrm{~Pb}$ age base of the Darriwilian Stage may be considered to have an isotopic age of approximately $464 \mathrm{Ma}$.

\section{Acknowledgments}

The present research has been supported by NSF grant INT-9513128 and partially by CONICET (Argentina).

\section{References}

Bergström, S M, Huff, W D, Kolata, D R, Krekeler, M P S, Cingolani, C, and Astini, R A, 1996, Lower and Middle Ordovician K-bentonites in the Precordillera of Argentina: A progress report: XIII Congreso Geologico Argentino y II Congreso de Exploraticíon de Hidrocarburos, v. V, pp. $481-490$.

Bergström, S M, and Wang Zhi-hao, 1995, Global correlation of Castlemainian to Darriwilian conodont faunas and their relations to the graptolite zone succession: Palaeoworld, v. 5, pp. 92-100.

Chen Xu, and Bergström, S M, eds., 1995, The base of the austrodentatus Zone as a level for global subdivision of the Ordovician System: Palaeoworld, v. 5, $117 \mathrm{pp}$.

Chen Xu, Zhang Yuan-dong, and Mitchell, C E, 1995a, Castlemainian to Darriwilian (late Yushanian to early Zhejiangian) graptolite faunas: Paleoworld, v, 5, pp. 36-66.

Chen Xu, Mitchell, C E, Zhang Yuan-dong, Bergström, S M, Winston, D, Wang Zhi-hao, and Maletz, J, 1995b, Graptolite species succession across the base of the Undulograptus austrodentatus Zone at Huangnitang, south-central China, and its prospects for use as a global stage stratotype, in Cooper, J, Droser, M L, and Finney, S C eds., Ordovician Odyssey: Short papers for the Seventh International Symposium on the Ordovician System: Pacific Section Society for Sedimentary Geology (SEPM) Book 77, pp. 157-161.

Cooper, R A, 1992, A relative timescale for the Early Ordovician derived from depositional rates, in Webby, B D, and Laurie, J R, eds., Global perspectives on Ordovician geology: A A Balkema, Rotterdam, pp. 3-21.

Cooper, R A, and Lindholm, K, 1990, A precise worldwide correlation of early Ordovician graptolite serquences: Geological Magazine, v. 127, pp. 497-525.

Davis, D W, 1982, Optimum linear regression and error estimation applied to U-Pb data: Canadian Journal of Earth Sciences, v. 19, pp. 2141-2149.

Dunning, G R, and Krogh, T E, 1991, Stratigraphic correlation of Appalachian Ordovician using advanced $\mathrm{U}-\mathrm{Pb}$ zircon geochronology techniques: Geological Survey of Canada Paper 90-9, pp. 85-92.

Huff, W D, Bergström, S M, Kolata, D R, Cingolani, C, and Davis, D W, 1995. Middle Ordovician K-bentonites discovered in the Precordillera of Argentina: Geochemical and paleogeographical implications, in Cooper, J, Droser, M L. and Finney, S C, eds., Ordovician Odyssey: Short papers for the Seventh International Symposium on the Ordovician System: Pacific Section Society for Sedimentary Geology (SEPM) Book 77, pp. 343-349.
Hünicken, M A, and Ortega, G C, 1987, Lower Llanvirn-lower Caradoc (Ordovician) conodonts and graptolites from the Argentine Central Precordillera, in Austin, R L, ed., Conodonts: Investigative techniques and applications: Ellis Horwood Ltd., Chichester, pp. 136-145.

Kolata, D R, Huff, W D, Bergström, S M, and Cingolani, C, 1994, Ordovician K-bentonite beds discovered in the Precordillera of Argentina: Geological Society of America Abstracts with Programs, v. 26, p. 503.

Nowlan, G S, and Thurlow, J G, 1987. The significance of Middle Ordovician conodonts from the Buchans Group: Geological Survey of Canada Paper 86-24, pp. 59-62.

Ortega, G, Albanesi, G L, Ottone, E G, and Holfelz, G D, 1996, Conodonts, palynomorphs, and graptolites from the Los Azules Formation, Argentine Precordillera: Sixth European Conodont Symposium, ECOS VI, Abstracts, p. 44.

Stewart, P W, 1987, Geology and genesis of granitoid clasts in the MacLean Extension transported orebody, in Kirkhan, R V, ed., Buchans geology, Newfoundland: Geological Survey of Canada Paper 86-24, Report 9, pp. 149-176.

Stouge, S, 1980, Lower and Middle Ordovician conodonts from central Newfoundland and their correlatives in western Newfoundland. Newfoundland Department of Mines and Energy, Current Research, Report 80-1, pp. 134-143.

Tucker, R D, Krogh, T E, Ross R J, Jr, and Williams, S H, 1990, Time-scale calibration by high-precision U-Pb zircon dating of interstratified volcanic ashes in the Ordovician and Lower Silurian stratotypes of Britain: Earth and Planetary Sciences Letters, v. 100, pp. 51-58.

Tucker, R D, and McKerrow, W S, 1995, Early Paleozoic chronology: A review in light of new $\mathrm{U}-\mathrm{Pb}$ zircon ages from Newfoundland and Britain: Canadian Journal of Earth Sciences, v. 32, pp. 368-379.

Warren D. Huff is Professor of Geology at the University of Cincinnati where he has been a faculty member since 1963. He received his $B$. A. degree from Harvard University (1959) and his $\mathrm{Ph} . \mathrm{D}$ degree from the University of Cincinnati (1963). He teaches courses in clay mineralogy and has pursued research activities in the mineralogy, geochemistry, and paleovolcanology of lower Paleozoic K-bentonite. He has been a Titular Member of the Subcommission on Ordovician Stratigraphy since 1996.

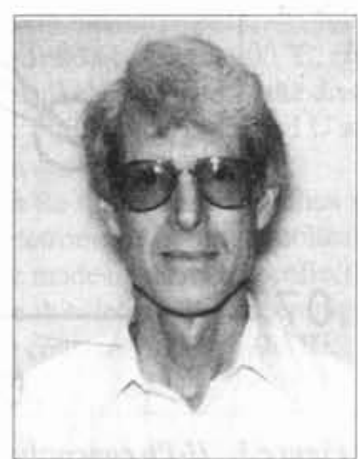


Donald W. Davis received his Ph.D. at the University of Alberta in 1978. Since that time, he has worked at the Jack Satterly Geochronology Laboratory in the Royal Ontario Museum and is now a curator. His work has largely concentrated on Archean crustal development in the Superior Province, but with occasional excursions into the Phanerozoic.

Stig M Bergström is Professor of Geological Sciences at The Ohio State University, USA where he has been teaching since 1968 after having received his graduate training at Lund University, Sweden. He has been a voting member of the Subcommission on Ordovician Stratigraphy since 1974 and served as subcommision secretary in 1976-1982. His pricipal research interest is global Ordovician geology, especial aspects of the evolution of the Iapetus, the significance of Lower Paleozoic $K$-bentonites, and conodont and graptolite morphology and biostratigraphy.

Mark M.P.S. Krekeler is completing his MS degree at the University of Cincinnati where he has concentrated on studies of the geochemistry and mineralogy of Argentine $K$-bentonites. He has received numerous awards and grants in support of his work and an active record of publication dating back to his early undergraduate days.

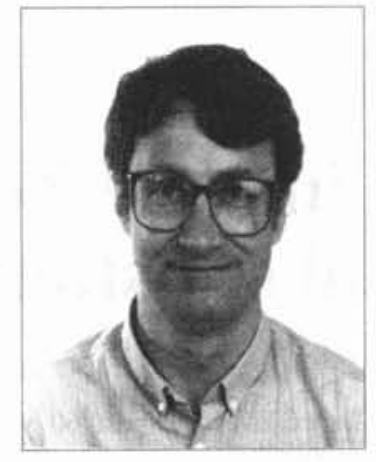

Dennis $\boldsymbol{R}$. Kolata is Senior Geologist and Head of the Sedimentary and Crustal Processes Section at the Illinois State Geological Survey (ISGS) and Adjunct Professor of Geology at the University of Illinois in Champaign, Illinois. He received his B. S. (1968) and M. S. (1970) degrees from Northern Illinois University and his $P h . D$ in geology (1973) from the University of Illinois. He began his career as a petroleum geologist with Texaco. In 1974, he joind the ISGS where he coodinates, supervises, and conducts research on the strutural and stratigrphical framework of the Midcontinent $U$. S. His research interests include the stratigraphic and tectonomagmatic significance of lower Paleozoic K-bentonite beds.

Carlos Alberto Cingolani is Professor of Historical Geology and Geotectonics at the University of $\mathrm{La}$ Plata and Principal Research Member of the National Council CONICET (calle 1 n. 644, 1900-La Plata, Argentina; e-mail: ccingola@cig. museo.unlp.edu.ar). Current topics of interest include: geotectonics, lithostratigraphy and crustal evolution of the Upper Precambrian and Lower Paleozoic from Southern and Western Argentina. Co-convenor on the Penrose Conference (GSA): "The Argentine Precordillera: a Laurentian terrane?", 1995, San Juan Argentina. Co-author of The Geodynamic Map of Gondwana Supercontinent Assembly (Patagonia and Rio de la Plata cratonic region), 1997 (IGCP, 288). Regional Coordinator of the SouthAmerican Symposium on Isotope Geology, SP, Brazil, 1997.
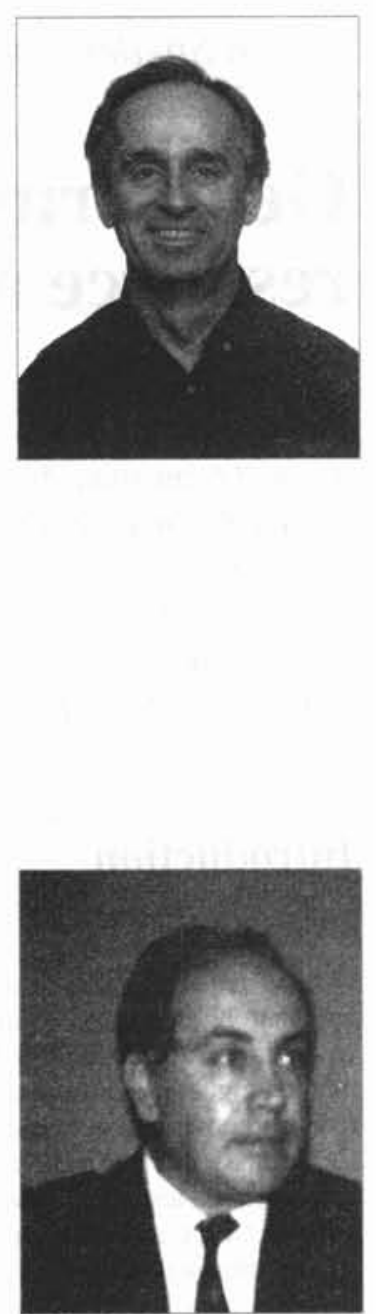